\title{
POTENSI ABU DAUN BAMBU DAN KOMPOS JERAMI UNTUK MENGENDALIKAN WERENG COKLAT
}

\author{
Ade Brian Nugraha ${ }^{1)}$, Retno Wijayanti ${ }^{2)}$ dan Subagiya ${ }^{2)}$ \\ 1) Mahasiswa S1 Program Studi Agroteknologi, Fakultas Pertanian, Universitas Sebelas Maret \\ 2) Staff Dosen Program Studi Agroteknologi, Fakultas Pertanian, Universitas Sebelas Maret \\ Kontak Penulis: unsbrian@gmail.com
}

\begin{abstract}
This study aims to determine the effect of the bamboo ash and straw compost on brown planthopper and rice production. This research was conducted in Bakaran, Sukosari Village, Jumantono, Karanganyar in $12^{\text {nd }}$ DecemberMarch 2017. The study was conducted using Complete Randomized Block Design (RCBD) in paddy fields consisting of 16 plots, each was $16 \mathrm{~m}^{2}$ with Bamboo Leaftreatment, Straw Compost, and Chemical Silica with SiO${ }_{2}$ of $200 \mathrm{~kg}^{-1}$ ha dosage. The variables observed were: Population of brown planthopper, stem hardness, plant height, number of tillers, number of productive tillers, weight of 100 seeds, weight of filled seed, hollow seed weight and percentage of hollow seeds. The data obtained were analyzed by Analysis of Variance (ANOVA) and if there was a significant difference, it followed by Duncans Multiple Range Test (DMRT) at $5 \%$ level. The results showed that bamboo leaf ash and straw compost not significan increase the hardness of the rice plant stems and brown planthopper population. Straw compost has the highest potential compared to other treatments because it produces the hardest stem rice and the lowest brown planthoppers population at 11 Weeks. The application of silica from various sources has no direct role in rice production.
\end{abstract}

Keywords: Brown planthopper, bamboo leaf ash, straw compost, hardness of rice stem

\section{AGROTECHNOLOGY RESEARCH JOURNAL}

Nugraha A B, Retno W, Subagiya. 2017. Bamboo leaf ash and straw compost potention on brown planthopper. Agrotech Res J 1(2): 7-12.

Nugraha A B, Retno W, Subagiya. 2017. Potensi abu daun bambu dan kompos jerami untuk mengendalikan wereng coklat. Agrotech Res J 1(2): 7-12.

\section{PENDAHULUAN}

Beras merupakan makanan pokok bagi hampir setengah penduduk dunia (Fairhurst dan Doberman 2002). Revolusi hijau yang telah sukses meningkatkan produksi padi meninggalkan kebiasaan pertanian dengan input yang tinggi. Kebiasaan petani dengan input yang tinggi tersebut menimbulkan beberapa dampak buruk yang diakibatkan tingginya kandungan nitrogen dari pupuk urea ditambah penggunaan pestisida yang dapat membunuh musuh alami hama sehingga mengakibatkan semakin seringnya ledakan hama seperti Ledakan wereng coklat yang terjadi tahun 1974, 1986, 1998 (Jawa Barat), 2010 (Jawa Barat, Jawa Tengah, Jawa Timur), 2013 (Jawa Timur) (Wiyono et al. 2014). Tingginya tingkat serangan hama selain terjadi karena faktor diatas juga diakibatkan oleh kekurangan unsur hara mikro dimana petani jarang sekali memasukan input berupa unsur hara mikro. Hara mikro seperti Silika merupakan unsur yang penting bagi produksi padi (Kumar 2014).

Silika $\left(\mathrm{SiO}_{2}\right)$ merupakan unsur yang diperlukan dalam jumlah banyak khususnya pada tanaman graminae termasuk padi (Brunings et al. 2009). Menurut Kyuma (2004) padi menyerap unsur Si $100-300$ kg/ha setiap dipanen. Silika berperan membangun struktur tanaman sehingga tidak mudah rebah dan lebih tegak (Kumar 2014). Silika juga membuat dinding sel yang lebih tebal sehingga penetrasi stilet (alat makan serangga) sulit untuk menembus dan mendapatkan makanan (Massey dan Hartley 2009).

Silika selain dari sumber kimia dapat pula didapatkan dari sumber alami, salah satu tanaman yang memiliki kandungan silika yang paling tinggi yaitu tanaman bambu. Abu daun bambu memiliki kandungan silika sekitar 58,3\% (Priyanto 2010). Sumber silika yang lain adalah jerami, jerami memiliki kandungan silika sebanyak 4-20\% (Ishizuka 1971). Daun bambu juga merupakan sumberdaya yang melimpah dan tidak termanfaatkan bagi manusia. Jerami yang tidak dikembalikan ke lahan akan menjadi faktor yang menyebabkan pemiskinan $\mathrm{Si}$ dan $\mathrm{K}$ tanah (Asmin dan Karimuna 2014). Pemanfaatan daun bambu dan kompos jerami sebagai pupuk silika yang berguna untuk meningkatkan ketahanan terhadap serangan wereng coklat dan peningkatan produksi padi patut untuk diteliti. Hasil penelitian ini diharapkan dapat memberikan informasi tentang potensi abu daun bambu dan kompos jerami terhadap populasi wereng coklat, pertumbuhan dan produksi padi.

\section{METODE PENELITIAN}

Penelitian ini dilakukan di Lahan Sawah Dusun Bakaran, Desa Sukosari, Jumantono, Kab. Karanganyar pada 12 Desember-Maret 2017. Alat-alat yang digunakan dalam penelitian ini adalah pnetrometer GY-1 (Range : $2-17 \mathrm{~kg} / \mathrm{cm}^{2}$, Akurasi 0.1 $\mathrm{kg} / \mathrm{cm}^{2}$, Plunger Diameter : $3.5 \mathrm{~mm}$ ), hand counter, alat tulis, meteran dan alat dokumentasi. Bahan yang digunakan antara lain pupuk silika (zeolit), kompos jerami, abu daun bambu, benih padi varietas mekongga dan pupuk ZA. Penelitian dilakukan dengan

${ }^{*}$ Fak. Pertanian UNS Surakarta

JI. Ir. Sutami 36 A Surakarta

Potensi Abu Daun Bambu dan Kompos Jerami untuk Mengendalikan Wereng Coklat (Ade Brian Mugraha, 7 Retno Wijayanti, Subagiya) 
menggunakan Rancangan Acak Kelompok Lengkap yang terdiri dari 16 petak yang masing-masing berukuran $40 \mathrm{~m}^{2}$. Petak tersebut terbagi dalam 4 Blok dan dalam 1 blok terdiri dari 4 petak untuk masingmasing 1 perlakuan/petak kemudian satuan sampel diambil 10 tanaman/petak sehingga menghasilkan 160 sampel tanaman. Perlakuan yang diberikan yaitu abu daun bambu, kompos jerami (Kandungan $\mathrm{SiO}_{2}$ : $4 \%$ ) (Ishizuka 1971), Silika Kimia (Kandungan $\mathrm{SiO}_{2}: 65 \%$ ) (Arifin dan Harsodo 1991), masing-masing diaplikasikan dengan kadar $\mathrm{SiO}_{2} 200 \mathrm{~kg}^{-1}$ ha dan Kontrol (tanpa

\section{HASIL DAN PEMBAHASAN}

\section{Populasi wereng coklat}

Pengamatan populasi wereng coklat dimulai saat tanaman berumur 3 MST (Minggu Setelah Tanam) sampai dengan 12 MST dengan metode mutlak yang diamati sekali dalam satu minggu. Populasi wereng coklat disajikan dalam Gambar 1.

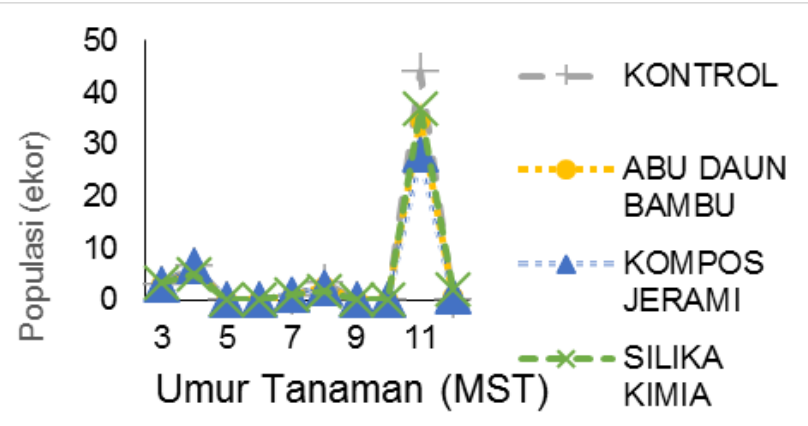

Gambar 1 Populasi wereng coklat berdasarkan umur tanam padi

Gambar 1 menunjukan terjadinya fluktuasi populasi yang sama pada semua perlakuan begitupula rata-rata populasi wereng coklat menurut analisis ragam tidak berbeda nyata antar perlakuan pada setiap waktu pengamatan. Pengamatan pada 3 MST dan 4 MST menunjukan adanya peningkatan populasi wereng makroptera (bersayap panjang) dengan rata-rata populasi pada perlakuan kontrol dan kompos jerami yaitu 7 ekor/ tanaman, sedangkan abu daun bambu sejumlah 6 ekor/tanaman dan silika kimia 5 ekor/tanaman. Peningkatan ini terjadi berkaitan dengan umur tanaman yang masih muda sehingga wereng coklat dari habitat lain baru menginvasi tanaman padi di lahan percobaan ini terlihat dari jenis wereng yang ditemukan yaitu wereng coklat makroptera (bersayap panjang).

Wereng coklat makroptera merupakan wereng dengan masa pre-oviposisi (masa sebelum bertelur) dan masa tanpa makanan lebih panjang yang digunakan untuk migrasi jarak jauh (Wada et al. 2009). Hal tersebut juga diperkuat oleh hasil penelitian Mochida dan Okada (1977) dimana masa pre-oviposisi makroptera adalah 3-8 hari sedangkan brakhiptera (sayap kecil) adalah 3-4 hari. Pengamatan pada minggu ke-8 memperlihatkan adanya wereng brakhiptera dengan jumlah 3 ekor/tanaman pada pemberian silika). Variabel yang diamati yaitu : Populasi wereng coklat, kekerasan batang, tinggi tanaman, jumlah anakan, jumlah anakan produktif, bobot 100 biji, bobott biji bernas, bobot biji hampa dan persentase biji bernas. Data yang diperoleh dianalisis dengan menggunakan analisis ragam atau Analysis of Varians (ANOVA) dan jika terdapat perbedaan yang nyata dilanjutkan dengan Duncans Multiple Range Test (DMRT) pada taraf 5\%. Analisisi korelasi juga digunakan dalam penelitian ini untuk mengetahui keeratan hubungan antar variabel.

tanaman kontrol dan 2 ekor/tamanan pada tanaman dengan pemberian silika.

Wereng brakhiptera memiliki karakteristik bertubuh lebih besar, ovipositor (peletak telur) lebih besar yang berguna untuk bereproduksi, munculnya brakhiptera ini terjadi karena sedikitnya populasi didalam rumpun tanaman hal ini sesuai dengan penelitian Baehaki (1985) dimana pada pemeliharaan 5 ekor nimfa/batang hanya muncul brakhiptera, jantan makroptera dan jantan brakhiptera sedangkan betina makroptera hanya muncul pada kerapatan 20 ekor nimfa/batang. Pengamatan 9 MST dan 10 MST tidak ditemukan imago wereng coklat tetapi terlihat nimfa instar 1 dengan karakteristik mesotonum dan metanotum masih berbentuk seperti buku sederhana dengan ukuran panjang tubuh $\pm 1 \mathrm{~mm}$ dan berwana putih yang berada di pangkal tanaman seperti yang dijelaskan Mochida (1979).

Jumlah pasti nimfa tidak terhitung jumlahnya. Ratarata wereng coklat/tanaman memilki angka yang sama pada pengamatan 3 MST-10 MST tetapi pada pengamatan 11 MST menunjukan populasi wereng yang cenderung berbeda yaitu pada kompos jerami denga rata-rata populasi yangpaling rendah dengan 28 ekor/tanaman, kemudian populasi terbanyak pada tanaman kontrol sebanyak 44 ekor $^{-1}$ tanaman disusul dengan silika kimia 37ekor ${ }^{-1}$ tanaman dan abu daun bambu 34ekor ${ }^{-1}$ tanaman. Perbedaan rata-rata populasi wereng pada pemberian kompos jerami dan abu daun bambu cenderung lebih sedikit dibanding kontrol terjadi karena kompos jerami dan abu daun bambu mengandung silika yang berperan dalam proses pertahanan tanaman terhadap serangan hama melalui mekanisme physical barrier berupa peningkatan rigiditas dan abrasivitas jaringan, sehingga mengurangi digestibilitas serangga hama (Massey dan Hartley 2009). Hal tersebut nantinya akan mempengaruhi pemilihan induk serangga hama dalam memilih inang sebagaimana dikutip dari Yaherwandi et al (2009) bahwa batang yang keras dan daun yang kasar tidak disukai oleh wereng batang coklat, karena dapat menyulitkan wereng batang coklat saat menusukkan alat mulutnya untuk menghisap cairan tanaman dan dapat pula menyebabkan kematian pada nimfa karena tidak dapat makan. Hal tersebut seiring dengan hasil pengamatan kekerasan batang sebagai berikut 


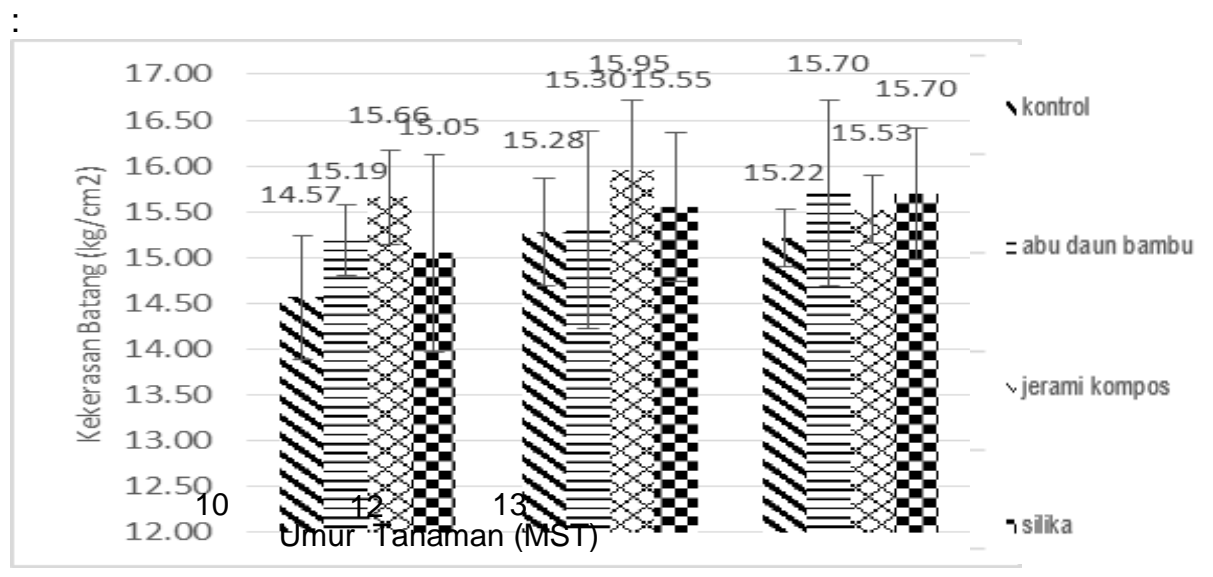

Gambar 2 Kekerasan Batang

Gambar 2 Menunujukan kekerasan batang perlakuan kompos jerami yang cenderung paling keras kemudian silika kimia dan abu daun bambu dan paling rendah kekerasannya yaitu tanaman kontrol. Terlihat adanya hubungan antara jumlah populasi wereng coklat pada 11 MST dan kekerasan batang sebagaimana hasil uji korelasi pada Tabel 2 yang menunjukan adanya korelasi signifikan( $(r=-0,602, \quad p=0.014, \quad n=16)$ yang berarti semakin keras batangnya maka semakin rendah populasi wereng coklatnya.

Perlakuan kompos memiliki kecederungan tingkat serangan wereng pada $11 \mathrm{MST}$ yang lebih rendah dan memiliki kekerasan batang yang lebih kuat dari perlakuan lain hal ini terjadi karena adanya perbedaan proses yaitu komposting dan pembakaran dan juga karena adanya kandungan yang hanya dimiliki kompos jerami atau kandungan yang lebih tinggi dalam kompos jerami dibandingkan dengan sumber silika lain yaitu abu daun bambu dan silika kimia. Unsur hara yang memiliki peran dalam mempengaruhi tingkat serangan hama dan kekerasan batang selain silika yang tidak dimiliki oleh sumber silika lain adalah unsur fosfor. Buckman dan Brady (1982) menyatakan bahwa fosfor membantu menjaga keseimbangan dari efek pemberian nitrogen yang berlebihan, merangsang pembentukan jaringan dan dapat memperkuat jaringan serta dinding sel sehingga diyakini dapat membuat tanaman menjadi resisten.

Kandungan fosfor dalam kompos jerami menurut Fairhurst dan Dobermand (2002) adalah sebanyak $0.16-0.27 \%$, abu daun bambu menurut Olugbenga et al. (2010) tidak memiliki kandungan fosfor, efek pembakaran pada pembuatan abu menurut Fairhurst dan Dobermand (2002) kandungan fosfor akan hilang $25 \%$. Fosfor juga tidak dapat ditemukan dalam zeolit, menurut Arifin dan Harsodo (1991) kandungan silika kimia (zeolit).

Pengamatan terakhir pada 12 MST menunjukan penurunan populasi sampai rata-rata 0ekor/tanaman untuk perlakuan kontrol, kompos jerami dan abu daun bambu, pada silika kimia hanya tersisa 1 wereng/tanaman yang terjadi akibat migrasi makroptera karena tanaman yang sudah kering (mendekati panen) hal ini sesuai dengan pernyataan Baehaki (2012) bahwa wereng menyebar dengan cepat ke habitat baru sebelum habitat lama tidak lagi berguna, selain migrasi banyak juga ditemukan wereng coklat yang mati hal ini karena wereng coklat yang sudah tidak bisa lagi mengakses makanan dari tanaman padi.

\section{Komponen pertumbuhan dan produksi padi}

\section{Tinggi tanaman}

Pertumbuhan pada tanaman padi identik dengan fase vegetatif, dalam penelitian ini variabel pertumbuhan yang diamati yaitu tinggi tanaman, jumlah anakan serta jumlah anakan produktif. Tinggi tanaman dapat dilihat dalam Tabel 1 sebagai berikut :

Tabel 1 Pengaruh Silika kimia, abu daun bambu dan kompos jerami pada tinggi tanaman.

\begin{tabular}{lr}
\hline Sumber Silika & Tinggi Tanaman $(\mathrm{cm})$ \\
\hline Tanpa Silika & $101.63 \pm 6.20 \mathrm{a}$ \\
Abu Daun Bambu & $103.67 \pm 2.13 \mathrm{a}$ \\
Kompos Jerami & $106.56 \pm 2.70 \mathrm{a}$ \\
Silika Kimia & $104.02 \pm 2.10 \mathrm{a}$
\end{tabular}

Keterangan : Hasil diperoleh dengan DMRT 5\%.

Tabel 1 menunjukan perbedaan tinggi tanaman yang tidak berbeda nyata antar perlakuan tetapi tetap menunjukan perbedaan dengan tren yang sama seperti pada varibel populasi wereng dan kekerasan batang dimana kompos jerami memiliki tinggi tanaman tertinggi disusul abu daun bambu dan silika kimia yang hampir sama dan tinggi tanaman paling rendah yaitu perlakuan kontrol. Tinggi tanaman pada kompos jerami yang lebih tinggi sesuai dengan penelitian Elizabeth (2013) dimana pemberian kompos jerami berpengaruh nyata dalam meningkatkan tinggi tanaman hal ini terjadi berhubungan dengan meningkatkan ketersediaan nitrogen dalam tanah dan serapan nitrogen oleh tanaman. Abu daun bambu kehilangan kandungan nitrogen pada saat pembakaran menurut Rosinta (2013) berkurang sampai $80 \%$. Pupuk zeolit sebagai pupuk silika kimia memiliki kemampuan untuk menjerap nitrogen dalam bentuk ion ammonium sehingga tidak mudah tercuci oleh air dan nitrogen lebih tersedia untuk tanaman (Nurul 2006).

\section{Jumlah anakan dan jumlah anakan produktif}

Tanaman padi membentuk rumpun dengan anakannya, biasanya anakan akan tumbuh pada dasar batang. Pembentukan anakan terjadi secara tersusun 
yaitu pada batang utama akan tumbuh anakanan pertama, anakan kedua tumbuh oada batang bawah anakan pertama, anakan ketiga tumbuh pada buku pertama pada batang anakan kedua dan seterusnya. Semua anakan memiliki bentuk yang serupa dan membentuk perakaran sendiri (Luh 1991).

Tabel 2 Jumlah Anakan dan Jumlah anakan produktif per rumpun

\begin{tabular}{lrr}
\hline Sumber Silika & Jumlah Anakan & Jumlah Anakan Produktif \\
\hline Tanpa Silika & $10 \pm 0.50 \mathrm{a}$ & $8.6 \pm 0.20 \mathrm{a}$ \\
Abu Daun Bambu & $11 \pm 1.02 \mathrm{a}$ & $9.2 \pm 0.94 \mathrm{a}$ \\
Kompos Jerami & $10 \pm 1.10 \mathrm{a}$ & $8.9 \pm 1.08 \mathrm{a}$ \\
Silika Kimia & $11 \pm 0.77 \mathrm{a}$ & $9.2 \pm 1.09 \mathrm{a}$
\end{tabular}

Banyaknya anakan (terutama anakan produktif merupakan salah satu kunci peningkatan produktivitas tanaman padi. Semakin banyak anakan produktif tanaman padi akan seakin banyak pula malai yang terbentuk dan akhirnya semakin banyak biji yang dihasilkan oleh tanaman tersebut. Rerata jumlah anakan padi per rumpun ditunjukan pada Tabel 2 .
Tabel 2 memperlihatkan jumlah anakan per sampel yang tidak berbeda nyata. Menurut Sugeng (2001) jumlah anakan yang terbentuk dipengaruhi oleh beberapa faktor diantaranya varietas. Setiap varietas memiliki perbedaan genetik yang dapat mempengaruhi pertumbuhan yang berbeda-beda. Pengaruh kompos

\section{Produksi Padi}

Produksi padi yang diamati dalam penelitian ini yaitu Berat 100 biji, berat total bernas, berat biji hampa, persentase bernas-hampa, semua variable diamati setelah pemanenan.

Berat biji adalah salah satu peubah yang dapat dijadikan sebagai indikator utama dari hasil suatu tanaman. Penentuan berat 100 biji dapat digunakan

Tabel 3 Pengaruh Silika kimia, Abu Daun Bambu dan kompos jerami terhadap bobot 100 biji padi

Sumber Silika

Tanpa Silika Bobot $100 \mathrm{Biji(gram)}$

Abu Daun Bambu

$2.8 \pm 0.175 \mathrm{a}$

Kompos Jerami

$2.9 \pm 0.130 \mathrm{a}$

Silika Kimia

$2.9 \pm 0.107 \mathrm{a}$

$2.8 \pm 0.140 \mathrm{a}$

Keterangan : Hasil diperoleh dengan DMRT 5\%

Sumber : Data Pengamatan

Tabel 3 menunjukkan bahwa tidak ada perbedaan diantara semua perlakuan terhadap berat 100 biji. Hasil penelitian tersebut sesuai dengan penelitian Lubis et al. (2013), perlakuan silika kimia tidak berpengaruh nyata

terhadap jumlah anakan juga sesuai dengan penelitian Febriyanti et al. (2013) yang memperlihatkan tidak ada pengaruh yang signifikan antara perlakuan dan jumlah anakan. Pemberian kompos jerami dan abu daun bambu juga tidak berpengaruh nyata terhadap jumlah anakan produktif.

untuk memberikan informasi tentang keseragaman biji yang dihasilkan oleh setiap tanaman (Ratna 2015). Selain itu, penentuan berat 100 biji suatu tanaman juga dapat digunakan untuk mengetahui produktivitas suatu tanaman pada suatu luas tertentu yang diharapkan dapat menentukan hasil dari suatu varietas yang dapat beradaptasi dengan lingkungan (Kuswanto 1997). Data berat 100 biji disajikan dalam Tabel 3 .

Tabel 4 Pengaruh Silika kimia, abu daun bambu dan kompos jerami terhadap produksi padi

\begin{tabular}{lrrrr} 
Sumber Silika & $\begin{array}{r}\text { Bobot biji Bernas } \\
(\mathrm{gram})\end{array}$ & $\begin{array}{r}\text { Bobot Biji Hampa } \\
(\mathrm{gram})\end{array}$ & $\begin{array}{r}\text { Total bobot Biji } \\
(\mathrm{gram})\end{array}$ & $\begin{array}{r}\text { Persentase Biji } \\
\text { Bernas }(\%)\end{array}$ \\
\hline Tanpa Silika & $10.4 \pm 0.7 \mathrm{a}$ & $3.6 \pm 1.02 \mathrm{a}$ & $14.0 \pm 1.63 \mathrm{a}$ & $74.3 \pm 4.09 \mathrm{a}$ \\
Abu Daun Bambu & $12.3 \pm 2.62 \mathrm{a}$ & $3.4 \pm 0.5 \mathrm{a}$ & $15.8 \pm 2.78 \mathrm{a}$ & $78.0 \pm 4.19 \mathrm{a}$ \\
Kompos Jerami & $12.5 \pm 3.57 \mathrm{a}$ & $3.5 \pm 0.63 \mathrm{a}$ & $16.0 \pm 3.68 \mathrm{a}$ & $77.5 \pm 5.73 \mathrm{a}$ \\
Silika Kimia & $11.2 \pm 2.46 \mathrm{a}$ & $3.3 \pm 0.43 \mathrm{a}$ & $14.5 \pm 1.8 \mathrm{a}$ & $76.9 \pm 1.75 \mathrm{a}$ \\
\hline
\end{tabular}

Keterangan : Hasil diperoleh dengan DMRT 5\%.

Tabel 4 Menunjukan perlakuan kompos jerami dan abu daun bambu memiliki bobot biji bernas yang lebih tinggi dibanding perlakuan kontrol karena kompos jerami dan Abu daun bambu memiliki kandungan kalium yang berperan dalam proses pengisian biji (Febriyanti et al. 2013). Bobot total isi juga dipengaruhi diperngaruhi oleh serangan wereng, terlihat dari tren yang sama antara populasi wereng dan juga berat total, terhadap bobot 100 biji padi. Febriyanti et al. (2013) juga menyatakan pemberian kompos jerami terhadap bobot 100 biji. berat isi dan persentase biji isi-hampa biji dimana perlakuan kompos jerami, silika kimia dan abu daun bambu lebih tinggi dari kontrol. Data persentase biji isihampa pada Tabel 4. memperlihatkan bahwa banyaknya bulir yang hampa, hal tersebut merupakan salah satu ciri serangan wereng coklat (Heong dan Hardy 2009). 


\section{KESIMPULAN DAN SARAN}

\section{Kesimpulan}

1. Kompos jerami dan abu daun bambu tidak berpengaruh terhadap populasi wereng dan kekerasan batang.

2. Kompos Jerami memiliki potensi paling baik dalam menurunkan populasi wereng dan kekerasan batang

3. Kompos jerami dan abu daun bambu tidak berpengaruh terhadap produksi dan pertumbuhan padi.

\section{DAFTAR PUSTAKA}

Arifin M, Harsodo. 1991. Zeolit alam, potensi, teknologi, kegunaan dan prospeknya di Indonesia, Pusat Penelitian dan Pengembangan Teknologi Mineral.

Arnon DI, Stout PR. 1939. The essentiality of certain elements in minute quantity for plants with special reference to copper. Plant Physiol. 14 : 371-375.

Asmin, Karimuna. 2014. Kajian Pemupukan Kalium Dengan Aplikasi Jerami Padi Terhadap Pertumbuhan dan Produksi Padi Sawah Padalahan Sawah Bukaanbarudi Kabupaten Buton, Sulawesi Tenggara. Jurnal Agroteknos Vol.4 : 180-188. ISSN : 2087-7706.

Baehaki, S.E 1985. Studi Perkembangan Populasi Wereng Coklat (Nilapavarta lugens Stal) Asalimigran dan Pemencarannya di Pertanaman. Disertasi. Institut Pertanian Bogor.

Baehaki, S.E. 2009. Strategi Pengendalian Hama Terpadu Tanaman Padi dalam Perspektif Praktek Pertanian yang baik (Good Agricultural Practices). J Pengembangan Inovasi Pertanian. 2(1) : 65-78.

Baehaki, S.E. 2012. Perkembangan biotipe hama wereng cokelat pada tanaman padi. IPTEK Tanaman Pangan 7 (1) : 8-17.

Buckman, H.O, N.C. Brady. 1982. IImu Tanah. Bhratara Karya Aksara. Jakarta. 788 hal.

Brunings A.M, L.E. Datnoff, J.F. Ma, N. Mitani, Y. Nagamura, B. Rathinosabapathi, M. Kirst. 2009 Differential gene expression of rice in response to silicon and rice blast fungus Magnaporthe oryzae. Ann. Appl. Biol.155:161-170.

Elizabeth K. 2013. Pengaruh Kompos Jerami dan Pupuk NPK terhadap N-Tersedia Tanah, Serapan-N, Pertumbuhan dan Hasil Padi Sawah. Prosiding FMIPA Universitas Pattimura 2013. ISBN : 978-60297522-0-5.

Epstein E, Bloom AJ. 2003: Mineral Nutrition of Plants: Principles and Perspectives, 2nd Ed., John Wiley \& Sons, New York.

Fairhurst T.H, A. Doberman. 2002. Rice in The Global Food Supply. Better Crops International Vol. 16 : 36.

Febriyanti I.S, Jonatan G, T. Irmansyah. 2013. Pertumbuhan dan Produksi Padi GOGO Varietas Situ Bagendit pada Jarak Tanam yang berbeda dan Pemberian Kompos Jerami. Jurnal Online Agroekoteknologi VOI.2 98-111. ISSN : 2337-6597.

Heong KL, Hardy B. 2009. Planthoppers: New Threats to the Sustainability of Intensive Rice Production

\section{Saran}

Saran yang dapat diberikan untuk penelitian selanjutnya terkait penelitian ini adalah perlu dipersiapkannya alat untuk mengukur variabel seperti pnetrometer sebelum dimulai penelitian.

Systems in Asia. Los Banos (PH): International Rice Research Institute.

Ishizuka, Y. 1971. Physiology of the rice plant. Adv. Agron., 23: 241-315.

Kumar S.D. 2014. Role of micronutrient in Rice Cultivation and Management Strategy in Organic Agriculture. Agricultural Sciences Vol.5 : 765-769.

Kuswanto, H. 1997. Analisis Benih. Penerbit Andi. Yogyakarta.

Kyuma, K. 2004. Paddy Soil Science. Kyoto University Press, Kyoto, Japan, ISBN : $9781920901004 \mathrm{Hal}$ : 280.

Lubis T. Ahmad., Zulkifli N dan Sarifuddin. 2013. Pengaruh Air Laut, Zeolit dan Pasir Vulkan terhadap status Hara pada Tanah Gambut serta pertumbuhan dan Produksi Padi Sawah. Jurnal Online Agroekoteknologi. 2 (1) : 13-25. ISSN : 2337-6597.

Luh, B. S., 1991. Rice. Second Edition. Van Nostrand Reinhold. New York.

Massey F. P., Hartley S. E. 2009. Physical defences wear you down: progressive and irreversible impacts of silica on insect herbivores. J Anim. Ecol. 78 281291. 10.1111/j.1365-2656.2008.01472.x

Mochida, Okada. T. 1977. Taxonomic characters for identification of the rice brown planthopper ( Nilaparvata lugens ) and its related species in the Asian and Pacific region. Pages 1-25 in The rice brown planthopper. FFTC (ASPAC). Taipei.

Mochida O. 1979. Brown planthoppers reduce rice production. Indonesian Agricultural Research \& Development Journal. 1(1/2):2-7, 24.

Nurul H. 2006. Peranan Zeolit dalam Pelepasan Nitrogen dari Pupuk Tersedia Lambat (Slow Release Fertilizers). Skripsi Departemen IImu Tanah dan Sumberdaya Lahan Fakultas Pertanian IPB.

Olugbenga O. Amu, Akinwole A. Adetuberu 2010. Characteristics of bamboo leaf ash stabilization on lateritic soil in highway construction. Int J Eng Tech. 2, pp. 212-219.

Priyanto A. 2015. Sintesis dan Aplikasi Silika dari Abu Daun Bambu Petung (Dendrocalamus Asper (Schult.F.) Backer Ex Heyne) untuk Mengurangi Kadar Ammonium dan Nitrat pada Limbah Cair Tahu. Skripsi FITK. UIN Semarang.

Ratna R.L., Rasi K.S., Revandy IM. 2015. Respons Pertumbuhan dan Produksi Kedelai (Glycine Max (L.) meriill) terhadap pemberian Kompos Sampah Kota dan Pupuk P. J Agroekologi.4 (1) 1838-1848. E-ISSN : 2337-6597.

Sugeng, H. R. 2001. Bercocok Tanam Padi. Aneka Ilmu. Semarang. 
Wiyono S, Widodo, Hermanu T. 2014. Mengelola Ledakan Hama Dan Penyakit Padi Sawah Pada Agroekosistem Yang Fragil Dengan Pengendalian Hama Terpadu Biointensif. Risalah Kebijakan Pertanian dan Lingkungan. 1 (2) : 116-120. ISSN : 2355-6226.

Wada T, Kiyomitsu I, Akihiko T, Jian Tang. 2009. Starvation tolerance of macropter brown planthopper, Nilaparvata lugens, from temperate, subtropical, andtropical populations in East and South-East Asia. J Entomologia Experiments et Applicata. $130: 73-80$.

Yaherwandi. 2009. Struktur Komunitas Hymenoptera Parasitoid Pada Berbagai Lanskap Pertanian Di Sumatra Barat. Jurnal Entomologi Indonesia. 6 (1) : 1-14. 